\title{
COMPANY STRATEGIC MARKETING MANAGEMENT - SYNERGIC APPROACH AND VALUE CREATING
}

\author{
I. Šimberová
}

Received: September 26, 2010

\begin{abstract}
ŠIMBEROVÁ, I.: Company strategic marketing management - synergic approach and value creating. Acta univ. agric. et silvic. Mendel. Brun., 2010, LVIII, No. 6, pp. 543-552

The paper aims to introduce a synergic approach to the strategic marketing management, which appears to be a challenge with respect to enhancing competitiveness of industrial companies in a small open economy. The potential of these companies consists in managing relations with the key stakeholders, which by means of effective establishing, maintaining and terminating of the mutual relations leads to developing of marketing networks, enables more effective tradeability of their offers, besides domestic embracing also global markets. The success of these relationships depends on the quantity and quality of mutual exchanges and in particular on the strengthening socially and knowledge-based links. The theoretical principles underlying the synergic approach within the marketing management are closely connected with the present marketing concepts, a new approach to the value creating, effectiveness of marketing activities and will form a basis for research of the industrial companies within the Czech Republic with the orientation to marketing activities effectiveness and performance of the company. The methods used in the paper are secondary analysis of statistics, analysis of scientific and professional literature, reports and researches of authors. The scientific aim of the paper is to review of current situation in this area and to create theoretical basis for the research on the industrial market.
\end{abstract}

strategic marketing management, synergic approach, value creation, industrial market, effectiveness, competitiveness

The turbulent environment (increasing competitive pressure, growing demands of customers and other stakeholders, dynamism in development, obsolescence of technologies and products, increasing interventions of the European Union bodies and public authorities, the changing perception and behaviour of customers, the changing character of competition etc.) makes managements and owners of businesses seek, in addition to other things, new and more effective managerial, marketing and commercial approaches that will provide their successful enterprising not only on the domestic markets, but also their penetrating European, international and even global markets. In view of all that it is certainly a matter of necessity to look for new approaches that would make it possible for the traditional industries to do well in the described conditions.

\section{MATERIALS AND METHODS}

The paper is based on secondary analysis of statistics, scientific and professional literature, reports and researches of authors. It is review of current situation in this area and theoretical basis for the research on the industrial market.

Within the assessment of industry competitiveness the COM (2007) 374 report concludes that industry continues to be an important driving force of 
European economy. Specifically it creates approximately one fifth of the EU product. It is absolutely essential for innovation; it accounts for $81 \%$ of private sector expenditures on research and development and provides an increasing number of highly qualified jobs. Industry indirectly impacts dynamics of many service industries, whereby significantly contributing to employment growth. That is why industry plays the key role in transforming Europe into knowledge economy. The main task of industrial policy at EU level is to actively create the right framework conditions for development of businesses and innovation, for the EU to be attractive for investment and job creation in industry, while taking into account that most of the businesses are small and medium-sized ${ }^{1}$.

Another major global trend, developing in parallel, is the growing importance of the tertiary sector, i.e. the service sector, which in recent years can be observed, too, within the Czech Republic. Despite the fact that the economic structure of the Czech Republic still differs in the proportional sizes of its individual sectors from those of western type, the tertiary sector within the CR economic structure has been steadily gaining in importance. The slower growth rate of the service sector in CR is due to the traditionally strong position of industrial production. On the other hand, however, industrial production creates opportunities for the development of what is known as business related services (BRS). It is now generally known that the service sector; whether regarding distribution, enterprising or network services or even services relating to public economic interest, contains on practically all world markets an evident growth potential $^{2}$. This fact even gains in interest considering that economists predict the continued development of service market as an indisputable trend and crossborder trading in services as another economy driving force in many countries. Although industrial production has been recently growing ${ }^{3}$ in the Czech Republic, the growth is mostly driven by companies under foreign control, which have been gradually gaining a dominant position in industry and whose production is largely intended for export. The trends in the industrial sector indicate: decline in new orders in the industrial sector in general; increase in foreign investors' sales from industrial production; Czech industrial companies being primarily focused on the domestic market; growing competition - push for changes in the production systems, organization structures, the growing role of information and communication technologies and knowledge, new types of services emerging, pressure for innovations and so on. (Šimberová,
2008). The analysis of economic sources, specialist publications, analyses of and reports on previous studies show that the key problem of Czech industrial companies despite the application of various new methods and approaches is the area of strategic management and coordination of their business and marketing activities. At the time of economic crisis which to a smaller or greater degree has affected all the advanced countries and industries, the push for competitiveness, innovativeness of market offers and general effectiveness of businesses has intensified.

Solution to the basic issue companies are faced with: "What philosophy should their marketing effort follow?", seems to be a complicated task given the tangle of oftentimes opposing interests resulting from different principles. Key appears to be the question of relations to the external and internal environments. The changes which should probably take place as regards direction of company strategies relate to flexibility and speed of adaptation to the new changes on the market, through creating innovative potential, knowledge potential, by building and maintaining relations with not only customers but also other key stakeholders, by means of a quality and well-founded process of producing a unique value for the target customer segments. A major role of the strategic marketing management has to be acknowledged here, whose main objective is to seek and manage the present as well as future opportunities for successful company operations on the target markets while making use of appropriate strategies, systems and their tools (Kotler, Keller 2007; Loštáková 2005). Market orientation, creating and building of long-term relations with key stakeholders through an offer which includes quality services, these appear to be the essential elements to bring the desired qualitative changes to the competitiveness of companies by increasing the value for customers, other key partners and stakeholders on the one hand, and, in the final outcome, of the general market value of a company on the other. An emphasis on creativeness, innovation and effectiveness in the process of preparing such competitive offers needs to be sought, apart from developing long-term effective relations with customers, just in the management of relations with the other key stakeholders who form part of both the internal and external environment of a company.

\section{THEORETICAL PRINCIPLES}

Using a combination of a number of marketing approaches within the strategic marketing management of a company (that are based on adhering

$1 \operatorname{COM}$ (2007) 374 Research of industrial politics in half of term. [online] [cit. 2009_04_10] Acceptable from http://www. mpo.cz/dokument36969.html.

2 Zdroj Ministerstvo průmyslu a obchodu ČR. [online] [cit. 2007_10_17] Acceptable from www.mpo.cz.

3 In 2006, in the first term got actually to most than twice increasing ' $11,9 \%$, source: Analysis of economic and sector development in CR in force of Ministry of industry and commerce, $1^{\text {st }}$ termof 2006. [online] [cit 2009_04_10] Acceptable from www.mpo.cz. 
to frequently similar principles, such as economy, flexibility, comprehensiveness, integrity, global scale, individualization, cooperation etc.) when dealing with contrary interests following from these principles within the marketing management of a company, is a sensible response to the changes and requirements inherent in the present time. In this context a term of holistic marketing (Bridgewater, Egan 2002; Kotler, Keller, 2007) is frequently referred to in literature, which in our opinion means that 'everything matters' in marketing, that marketing needs to employ a broad synergic perspective in addressing the challenges in a highly competitive environment of the present day. Approach to synergy in marketing management consists in planning, producing and communicating the value to customers through integrated marketing programmes which besides the perspective of the seller also encompass those of the buyer and other interested groups (key stakeholders of a company). All the marketing activities are coordinated so as to maximize their joint outcomes, which also brings subsequent values in the sphere of frugality. The precondition for the marketing management becomes first of all adoption of a marketing philosophy (in its synergic form) by a company management. Which is not usual with Czech industrial companies. The final outcome of the strategic marketing management is the creation, through establishing, building or possibly ending mutual relations, of a unique company asset known as marketing network. The individual aspects of creating these mutual relations are explored by Harrison and Freemen, 1999; Mitchell, et al., 1997; Bryson, 2003; Winn and Keller, 2001; Kotler, Keller, 2007; Payne, 2005 and others in their studies. The advantage of the synergic approach is that it enables maximizing of value creation through exploring and identifying new opportunities and benefits for customers within the spaces delineated by the individual synergic model approaches (see Fig.1 below). This approach also maximizes provision of value through honing the management of relations with customers, employees and other groups of stakeholders in business partnership, or at a higher level-relationship networks (marketing networks).

These relations should deepen through quality and well-founded processes of creating a unique value for the target customer segments, which is an inseparable part of the strategic marketing management. We believe the key to any examination of the relations with stakeholders is the theory of interaction, the ideas of establishing, building and possible ending of relations, elaborated particularly in the theory of relationship marketing. The strategic importance of creating and building of relationships with the employees and other stakeholders in the environment of a relevant business is emphasized in relation to increasing the value provided for the main recipients (customers). Relationship marketing can be characterized as a process of cooperation between a company and its employees and other groups of stakeholders. Its goal is to develop profitable relations with customer segments based on their satisfaction and emotional engagement.
Approach of businesses to the adoption and implementation of the synergic marketing concept respects that the market and its demands are essential to setting goals, planning, organizing, decision-making, control and permanent contact with events taking place in the company environment. The marketing management primarily consists in choosing the target markets where it gains, maintains and extends the number of customers through processes of creation, provision and communication of value while fulfilling the economic goals of the company.

The importance of the strategic marketing management lies just in the fact that financial success very frequently depends on it, whereas finances, operations, accounting and other company functions lose their weight once the demand for products and services has dropped and become insufficient. The greatest risk is taken by companies who do not monitor their customers, competitors and other key stakeholder groups and fail to continuously improve their value offers. The quality and efficient process of marketing management is a never-ending activity. It is just the dynamics of the present environment which suggests that careful watching for potential opportunities that may bring with them increase in the value for customers, while along with that for the company as well, is at the heart of the approach.

An important idea for improving the corporate performance appears to be the connection of the reactive (understanding and satisfying of the expressed customer needs) and proactive marketing approaches (understanding and focusing on the latent customer needs), appearing in association with the total market orientation and provides room for the potential company innovation. The key point for directing of the total market orientation mainly consists in its embracing the other stakeholder groups through creating and consolidating relations with them. Such extension allows for better coordination of activities between the different parties resulting in mutual benefit which creates room for achieving the competitive advantage.

This approach (following from the holistic one) also embraces social responsibility within the company marketing activities (SRM-Social Responsibility Marketing). This primarily means understanding of the broader interests and the ethical, ecological, legal and social context of marketing activities and programmes (Kotler, Keller; 2007). Awareness of the social and ethical aspects is an important part of the sustainable development priorities. Frequently, this mainly involves the provision and maintenance of balance between the conflicting criteria of the company profits, customer satisfaction and public interests. In relation to this approach a 'shared marketing' appears on the practical level (Kotler, Keller; 2007). This involves support to solving problems of a specific target group through linking a company or its offer to specific cases building a mutually beneficial relationship or partnership (e.g. environmental protection, support to socially 


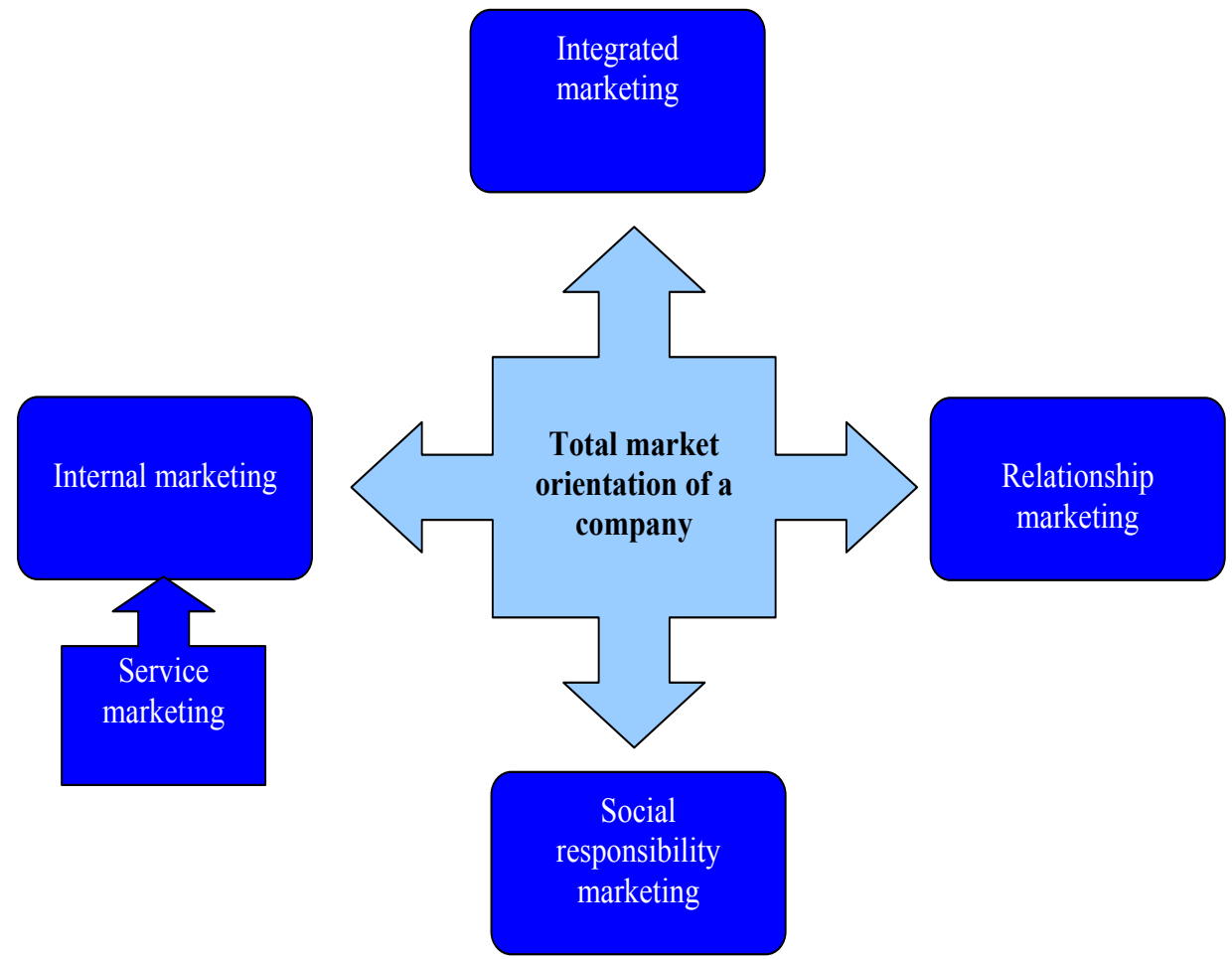

1: Synergic marketing concept model (Kotler, Keller, 2007; Šimberová, 2008)

disadvantaged groups etc.). The company success does not only depend on the quality of work of individual sections, but the quality of individual key processes and mainly their coordination has been more and more emphasized in recent time.

The internal marketing must ensure that everybody within the company supports the appropriate marketing principles. The precondition of success is that the main advocate and propagator of the relevant principles is in the first place the company management. The objective of internal marketing is to recruit, train and motivate competent employees to carry out and provide quality performance while presenting the company offers to its customers. The internal marketing activities take place at two levels: the first involves coordination of activities of various marketing functions (marketing research, sales representatives, promotion, customer services, product management etc. - they must work together). The second level concentrates on the necessary need of the marketing approach adoption by other departments, too, that should also think from the customer perspective. The basic initial approach within the building of the internal marketing is the service marketing, which provides the basis for the quality of the individual internal processes and thereby the space for creating the customer value. Providing a quality offer made up of products and services requires excellent internal marketing.
The market oriented strategic planning is a managerial process of developing and maintaining of the set goals, abilities and resources of a company in keeping with the changing conditions and opportunities on the market. The strategic planning has its hierarchy at several levels which must be respected. These include the corporate, SBU (basic and competitive) and SBU functional strategy levels. Within the strategies implementation attention should be extended to further involved 'subjects' / parties within the company (stakeholders) and the variety and interest preferences of these involved parties whose importance for company operation has been growing.

The integrated marketing approach consists in planning, producing and communicating value to customers through the integrated marketing programmes comprising apart from the seller's, the buyer's perspective, too (the marketing mix where $4 \mathrm{P}$ sellers correspond with $4 \mathrm{C}$ of the customer). All the marketing activities are coordinated in the way to maximize their joined results. The integrated marketing activities have to ensure that they together contribute to maximizing the turnover and the offer value.

The relationship marketing comprises the principle of creating, maintaining and or pertinently terminating permanent relationships with all individuals or subjects (stakeholders) who can, directly or indirectly influence the success of a company's mar- 
keting or business activities. It pursues the building of mutually beneficial long-term relations with key stakeholders to allow it for winning and maintaining of business relations based on strong economic, technical and social links between the partners. The final outcome of the relationship marketing is the creation of a unique company asset known as a marketing network. The establishing of beneficial strong relationships requires real understanding of the potential and means of various stakeholder groups, including their wishes, needs and goals.

The strategic marketing management based on the synergy of approaches (total market orientation, relationship marketing, internal and integrated marketing, service marketing and socially responsible marketing) shifts the thinking of the management towards respecting the following principles:

- marketing is not a sphere falling under the marketing department only, on the contrary, it becomes a matter of interest for everybody;

- successful is such marketing that responds to changes and adapts to changes on its target markets;

- prosperity is produced through continuous seeking of opportunities while not relying on the past strengths;

- not all the company activities can be done at a topclass level, therefore it creates advantage to pass some of them to others, provided the company cannot perform them cheaper and better;

- concentration on key activities is the way to the top level;

- the basis of the company effort is the lifetime customer value;

- partnership relations with key stakeholders form the basis for the potential competitive advantages;

- communication integrating both internally and externally;

The objective of the model (see Fig. 1) is to combine the basic principles of the current marketing concepts and further the ability to achieve the synergy which interconnects the company marketing and business activities, bearing in mind the synergy in marketing management consists in planning, producing and communicating the value to customers through integrated marketing programmes which besides the perspective of the seller also encompass those of the buyer and other interested groups (key stakeholders of a company) (Šimberová, 2008). All marketing activities are coordinated so as to maximize their joint outcomes, which also brings subsequent values in the sphere of frugality. The integrated marketing activities have to ensure that they together contribute to maximizing the turnover and the offer value. To achieve this, clearly defined tools in the form of methods and metrics have to be available, allowing for interactive modelling of newly arisen situations that the environment makes the subjects react to in a swift manner.

Each new approach or concept makes a difference for companies primarily in the case that it helps boost its performance and has a positive influence on their economic results. Marketing can only gain more ground in companies provided that it offers transparent quantifiable tools for measurement of financial means invested in the proposed marketing strategies and programmes. Recently a number of publications and specialist articles have appeared solving these problems through measurement based on the Return on Investment (ROI) (Shaw, 1999; Davis, 2007; Kotler, Keller, 2007). This seems to be the way that can lead to marketing gaining a stronger position in companies. The application of ROI as the basic marketing tool of measurement also offers, in addition to other benefits, achieving of communication agreement between the various functional areas of a company (enables marketing to "talk" in the same language that emphasizes effectiveness of its planned and implemented activities). It improves planning, measuring and optimization of marketing strategies. Inclusion of the strategic perspective requires that attention is turned to other non-financial indicators such as customer lifetime values (Loštáková, 2005), to the sphere of marketing measurement, and should finally facilitate the understanding of the essential contrasts within marketing, i.e. that the achieving of a higher customer value does not necessarily have the form of a profit. Another approach to measurement is based on the necessary monitoring of marketing costs. The calculation of costs should be applied to each marketing programme based on individual activities (e.g. the Activity Based Cost accounting (ABC) method (Kaplan and Bruns, 1987) in order to determine whether these activities will lead to results that will justify the cost. Within the implementation of the marketing management synergic approaches, whose basis is to create and build relations with key stakeholder groups, it is important to realize that there are many other involved groups of individuals and their needs in play. Companies have largely focused on shareholders so far. The marketing approach comprising the relationship creation, maintaining and terminating points out that this perception must be changed and broadened towards key stakeholders. Here we have to emphasize the difference between the "Shareholder"and "Stakeholder"approaches, the latter following from the value management area. The stakeholder approach is broader, responding to immediate conditions of the current environment, besides the profitmaking goal there are other goals being given major attention, such as responsibility towards society and partnership that are included in the company strategic goals and all the company activities. Here we consider the premise formulating that "unless a company cares for its key stakeholders and creates and builds beneficial and ongoing relationships with them, it is never going to achieve sufficient and particularly long-term profits"(Harrison, Freeman, 1999; Christopher, Payne, 2002; Kotler, Keller, 2007; Šimberová, 2008). A question of the level of a company focus on the key stakeholder groups relates to 
the intents and strategies that the company plans to implement with the aim of developing relations with these groups connected by the mutual dynamic relations. The companies focusing on the high level of customer satisfaction by offering products and services of higher quality are aware that through this they contribute to higher satisfaction of their customers. This results in repeated purchases, growth and higher profits, and consequently satisfaction of the other involved group and individuals, but also in making further investments etc. The described cycle brings profits and growth. The focus on profit maximization, according to some authors, appears to be rather short-sighted (Doyle, 2000). Maximizing the value for shareholders, to the contrary, presents another approach likely to be increasingly engaged in future. This approach recommends the use of SVA - Shareholder Value Analysis (Kotler, Keller, 2007) when deciding on the marketing strategy to follow. Such an analysis is based on the premises that a higher value of a company is concealed in its intangible marketing activities - brands, market knowledge, customer and partner relationships. It is these assets that represent the way to long-term gains. The analysis itself makes it possible to ascertain what kind of alternative course of events will maximize the value for shareholders, which will in addition ensure that the management perceives marketing as an integral part of the general process of its activities (as opposed to it being a specific function only focusing on increasing the turnover or market share).

\section{DISCUSSION}

The aim of each entrepreneurial activity is to provide a value (in the form of an offer) for a customer with a profit. What becomes a key issue in the competitive environment today is searching for more effective ways to providing higher values for customers than the competition. The traditional view of the value process has been losing its potential. The mass markets have split up into plenty of micro-markets each of which has its own needs, expectations and preferences. The new understanding of value provision consists just in harmonizing the process of value provision with choosing, creating and communicating the higher value. The changes appearing as necessary while providing the company value at the same time are based on providing the market offer for target markets already well defined in advance. That is how marketing gains the key role right at the initial stage of value planning and value choice. Value choice forms a strategic part of marketing management: this essentially includes segmentation, targeting and placement of value on the target market (STP). Through determining the value of market offer with respect to target markets and identifying its appropriate placement then in the process of value provision the marketing further decides on specifications, prices and distribution of each product and accompanying services and maintenance. The last, third phase of the pro- cess of value creation and provision is its communication. In this phase making the best of the power of personal sale and other communication tools is essential, which in mutual integration should communicate promises that a company is able to deliver and that provide the expected value of the target segments. Each phase of this process makes demands on cost spending. The company is responsible for careful monitoring of its cost and output as to each value-creating activity and looking for ways to reduce the cost or improve output. Further new approaches within value creation also can include the concept of $3 \mathrm{~V}$ (Kumar in Kotler, 2007), based on three $V$ principles: 1. define a value segment or customers (and their needs); 2. define a value proposition; 3 . define a value network that will provide the promised service for you. The synergic marketing approach (based on the holistic one) offers new broader possibilities of value provision for a customer. Kotler, Keller (2007) states this involves integrated examination of value, value creation and value provision in pursuit of building long-term mutually beneficial relationships and shared prosperity of the key groups involved (stakeholders). Through achieving this profit growth is ensured, by increasing the number of customers, building the customer loyalty and achieving lifetime customer value. The structure of this marketing approach includes an answer to three crucial management issues:

1. Value research (How a company can identify new value-related possibilities); Value exists within as well as across markets which are dynamic and competitive by definition. Therefore a company needs a well defined strategy to research value. The creation of such a strategy, as the authors believe, requires understanding of the relations and interactions among three areas: an area for learning about customers (their existing as well as latent needs, needs of participation, freedom, stability and change), an area for company competences (a wide range against a targeted range of business activities, physical abilities against knowledge-based abilities) and an area for partners resources (horizontal partner relations, where a company chooses partners based on their abilities to make use of the relating market opportunities, and vertical partner relations making use of partner abilities to help the company in creating value).

2. Value creation (How a company can effectively create new value offers); in order to be able to use opportunities, companies need to know how value is created. New benefits for customers have to be identified, namely from the customer perspective, and further capitalize on one's industry key benefits and manage business partners from own workmate network. Relevant is the information about what the customer thinks, wishes, does and what worries them, who influences them, who they see and admire.

3. Value provision (How a company can use its abilities and material means to more effectively pro- 
vide new value offers); the value provision primarily involves substantial investment in infrastructure and competences. A company must become competent in managing customer relationships, internal resources and business partners (stakeholders).

In many prosperous contemporary companies we can observe a tendency to create marketing strategies based on clearly defined and expressively communicated value offers. The value offer is a sum of all reasons why a customer should purchase products and services from a company. The shift in the value offer in industrial markets can be observed in the structure of offer of industrial companies, where it is the services which provide a potential source of distinguishing their offer from the competitors'. In view of this fact it is necessary, within the processes of companies' value provision, to give attention to mutual integrating of quality elements, services and marketing into building of permanent and beneficial relations with key stakeholders, as these relations will then contribute to customer satisfaction. Customer satisfaction is a critical point in mutual maintaining of relations with them and thereby for follow-up maximizing of their lifetime value. Custom services and their quality are the one important factor of consolidating mutual relations. The sharing of mutual prosperity resulting from building of mutual beneficial relations with key interest groups (stakeholders) is an area of potential opportunities for creating such services that will increase satisfaction of customers.

\section{CONCLUSION}

Creating, building and termination of relations with stakeholders - the potential and opportunity for a new utility value offer. The reasons for creating long-term customer relations with a company mainly relate to the attractiveness of the provided value. A key area appears to be here the differentiation of a company offer from the competitors' particularly as regards quality and provision of secondary services. Value research relates to the total market orientation of a company, which includes the view across as well as within the markets where the company finds its potential stakeholders. 'Stakeholders' do not only include customers, but also the distribution intermediate links, banks, insurance companies, owners, managers and other company workers in various company departments, suppliers and subsuppliers, competitors, marketing research agencies, advertising and PR agencies, the media, interest associations, public and local authorities etc., in short all the subjects that may further contribute to increasing the value for customers (Kotler, Keller, 2007; Šimberová, 2008).

The information gathered about the company broader environment, the broad company ability to respond to and process the information to create value offers and push them forward within the company - this influences the competitive advantages so far and differentiation of the offer from the competition and finally enables the creation of a higher utility value for customers. An important foothold for a company in this connection is the choice of its key stakeholders and creating and building of beneficial long-term relations with those who can contribute within the process of creating of added utility value. A research into the reasons for creating and building of relations with individual stakeholders in a relevant industry may offer a potential for effective production of new value offers of a company.

The segmentation of stakeholders, their understanding, estimate of their strength, determination of priorities and specification of reasons why mutual relations developed, continued and ended, also create space for decision-making by the management and help establish in which phase of the value-creation chain the advantages won based on the existing or potential mutual relations with stakeholders can be utilized. (E.g. the main reasons can include mainly the mutually provided information, contacts, financial means and further material as well as non-material sources, ideas for innovation, quality, flexibility, orders, business opportunities, quality of services, products, building of renown, atmosphere etc. ${ }^{4}$ Stakeholders are not only customers, but also distribution interlinks, banks, insurance companies, managers and other staff of various company departments, suppliers and sub-suppliers, competition, marketing research agencies, advertising and PR agencies, media, interest groups, state and local administration etc. - simply all entities able to contribute further to the increase of the customer value (Kotler, Keller, 2007; Šimberová, 2008).

Another area for the competitive differentiation of a company appears to be just the analysis of the already provided mutual services with its key stakeholders.

The whole of this process of creating and building of stakeholder relations is conditioned by the character and possibilities of an industry where a company operates.

An important role in a company's decision-making on the selection, establishing and building of stakeholder relations is also played by the stage of a company's life-cycle. In the various phases of company development the priorities for selection, establishing and building of the mutual relations change. This impacts its value creation process, too. A company just entering the market is likely to put an emphasis in the first place on creation of such marketing programmes and activities that will provide winning new customers. Establishing and building relations with customers and further stakeholders gains in importance during the following phases of company development. The potential and opportunity for value creation, however, should be sought by a company at any stage of its development. The correct choice of target segments is critical to placing the company value offer. Within the following phases of company development, the critical aspect for making decisions is just the monitoring of the total costs relating to winning new customers and their comparison with the total cost of maintaining and building the relations with the existing customers.

As mentioned before, with respect to all the phases of company development the key strategic point primarily appears 
to be thorough segmentation, choice of target markets and placement of value offer on the markets. The different markets may be segmented in different ways. The segmentation of the industrial market, based on customer needs, as the tool of strategic marketing management gains in general importance for the whole company and comprises several part steps that are comprehensively described in a "B-to-B marketing" publication: "Strategic analysis for creating of market opportunities“ (Loštáková, 2005). In association with research we need to point out another three major groups of segmentation variables, specifically the services-based segmentation, value-based segmentation and industry-based segmentation, that appear as significant for the stakeholder relations management and the follow-up key activities supporting the establishment and building of beneficial long-term relations.

As shown by the studies undertaken so far (Loštáková et al., 2009), the companies within the Czech Republic have actively engaged in looking for customers, learning about their needs and requirements and creating offers and customer care systems for them, often in a differentiated manner depending on a customer importance for the company. What has not been adequately developed in the companies so far is a system of efficient, swift and effective transformation of market-focused intents into the other company activities and relationships with other partners within the given business who possess the potential to contribute to increasing the value for customers, i.e. into the relations with stakeholders.

The market care also needs to be developed on the basis of long-term effective relations with customers. The deepening differentiation of customer needs and wishes and dramatic stiffening of competition has created the necessity to develop a broadly differentiated embracing even individualized system of customer care, depending on their needs and requests, through creating a special value for them (Peppers, Rogers; 2004) at the same time considering their potential value (lifetime value) for the company, i.e. based on the current value of all the future gains and other benefits that the company gets by selling to customers (Best, 2005; Loštáková et al., 2009).

Currently it is not enough to offer customers only what they expect, but it is necessary to actively and creatively collaborate with customers and other partners within the business in creating a unique value for the target markets. The thing to do is to seek, continuously and in mutual collaboration, new and new ideas for innovation and modification of products, ideas for improving the systems of contacting customers as well as improving the methods of ordering, distribution and provision of services (Prahalad, Ramaswamy; 2004). The value creation for customers should draw on a much broader spectrum of its dimensions, where besides the functional dimensions also the emotional and social dimensions have to be enhanced (Smith, Colgate, 2007; Šimberová, 2008).

However, we need to bear in mind that in today's changeable market environment business success does not only depend on how well companies manage to get to know and understand wishes of customers, their buyer and consumer behaviour, i.e. estimate what the dimensions of the best value for customers should be, but also on whether they can, and in what way, in mutual integration and cooperation within the company (Galbraith; 2005) and with their partners (stakeholders) outside the company create the value, deliver it and further perfect it, and even better and faster than the competition can do (Guenzi, Troilo; 2006). This requires an active team collaboration of persons within and outside the company, of managers and workers at different management levels and interconnecting of various in-house and external activities, thus creating a relationship network with stakeholders within the increasing of value for the target markets. This might be the way, as it has turned out, toward re-starting the growth of sales during the current period of the oncoming economic crisis. Unfortunately, these problems have not yet been given adequate attention, which particularly applies to businesses operating on B2B markets.

The present-time world marketing literature emphasizes the urgent need of identifying, creating, delivering, assessing and further perfecting of customer value, in a differentiated manner depending on the customer needs as well as on their value for the company, and outlines the four-phase - identify, create, provide and continuously improve the value for customers (e.g. Kotler, Jain, Maesincee; 2007) to five - phase concept of value management - discover, share, create, assess and improve the value for customers (e.g. DeBonis, Balinski, Allen; 2002). Individual stages are only outlined in a general manner, there are no methodical approaches included advising how to find, in mutual coordination between stakeholders, market opportunities, create successful market offers, share them with others, create a business architecture - culture, infrastructure, operating systems, processes and resources, deliver value and assess the relating processes and their outcomes with respect to their benefits for individual collaborating parties on the market, especially for customers, the company and its partners, and further perfect them.

\section{SOUHRN}

Strategický marketingový management podniku - synergický př́stup a tvorba hodnoty Celosvětová hospodářská krize a turbulentní tržní prostředí nutí podniky měnit přistupy k podnikání. Česká ekonomika představuje malý a poměrně saturovaný trh s relativně vysokým stupněm specializace průmyslu. Úspěšné fungování podniků je podmíněno mnoha faktory, jejichž vymezení je v centru zájmu teoretiků i praktiků již po dlouhé období. Turbulentní prostř̌edí (zvyšující se 
tlak konkurence, narůstající nároky zákazníků a ostatních stakeholdrů, dynamičnost ve vývoji, zastarávání technologií i produktů, narůstání zásahů orgánů Evropské unie (EU) a orgánů státu, měnící se vnímání a chování zákazníků, měnící se charakter konkurence atd.) nutí management a vlastníky podniků kromě jiného hledat nové a efektivnější manažerské, marketingové a obchodní přístupy, které zajistí jejich úspěšné podnikání nejen na tuzemských trzích, ale pronikat i na trhy evropské, mezinárodní a globální. Z toho důvodu je jistě nezbytné hledat nové př́stupy, které by umožnily tradičním průmyslovým odvětvím obstát v těchto podmínkách. Cílem příspěvku je představit synergický přístup v oblasti strategického marketingového managementu, který se zdá být výzvou pro zvýšení konkurenceschopnosti průmyslových podniků malé otevřené ekonomiky. Potenciál těchto podniků je v řízení vztahů s klíčovými stakeholdry, které formou efektivního vytváření, udržování a ukončení těchto vzájemných vztahů vede k vytváření marketingových sítí, umožňuje efektivnější obchodovatelnost jejich nabídky, a to nejenom na domácích, ale i mezinárodních, př́ípadně globálních trzích. Úspěch těchto vztahů je závislý na množství a kvalitě vzájemných výměn (zahrnujících jak výměnu produktů, tak služeb, informací apod.) a zejména na rostoucích sociálně a znalostně založených poutech. Teoretická východiska synergického př́stupu v strategickém marketingovém managementu jsou založená na současných marketingových koncepcích, novém přístupu k tvorbě hodnoty, přístupech k měření efektivnosti a budou podkladem pro výzkum podniků zpracovatelského průmyslu v České republice. V příspěvku jsou uvedeny limity a možnosti dalšího výzkumu v této oblasti. Článek je založený na metodách analýzy statistických dat, odborných pramenů, výzkumných zpráv a závěrů vlastních výzkumů autorky.

strategický marketingový management, synergický přístup, tvorba hodnoty, průmyslový trh, efektivnost, konkurenceschopnost

\section{SUMMARY}

The worldwide economic crisis and turbulent market environment have forced companies to change their business approaches. Czech economy represents a small and relatively saturated market with a relatively high degree of industry specialization. Successful company operation is conditioned by multiple factors the definition of which has been the focus of interest of theorists as well as practitioners for a long time. The turbulent environment (increasing competitive pressure, growing demands of customers and other stakeholders, dynamism in development, obsolescence of technologies and products, increasing interventions of the European Union bodies and public authorities, the changing perception and behaviour of customers, the changing character of competition etc.) makes managements and owners of businesses seek, in addition to other things, new and more effective managerial, marketing and commercial approaches that will provide their successful enterprising not only on the domestic markets, but also their penetrating European, international and even global markets. In view of all that it is certainly a matter of necessity to look for new approaches that would make it possible for the traditional industries to do well in the described conditions. The paper aims to introduce a synergic approach to the strategic marketing management, which appears to be a challenge with respect to enhancing competitiveness of industrial companies in a small open economy. The potential of these companies consists in managing relations with the key stakeholders, which by means of effective establishing, maintaining and terminating of the mutual relations leads to developing of marketing networks, enables more effective tradeability of their offers, besides domestic embracing also global markets. The success of these relationships depends on the quantity and quality of mutual exchanges and in particular on the strengthening socially and knowledge-based links. The theoretical principles underlying the synergic approach within the marketing management are closely connected with the present marketing concepts, a new approach to the value creating, effectiveness of marketing activities and will form a basis for research of the industrial companies within the Czech Republic with the orientation to marketing activities effectiveness and performance of the company. The methods used in the paper are secondary analysis of statistics, analysis of scientific and professional literature, reports and researches of authors. The scientific aim of the paper is to review of current situation in this area and to create theoretical basis for the research on the industrial market.

\section{Acknowledgment}

The paper was supported by specific research of Faculty of Business and Management Brno University of Technology and was created as an one of theoretical results of the project "Measurement methods of marketing activities effectiveness and their application" reg. number FP-S-10-21. 


\section{REFERENCES}

BEST, R. J., 2005: Market-Based Management: Strategies for Growing Customer Value and Profitability. 4th ed., New Jersey: Prentice Hall, 506 p., ISBN 0-13-146956-8.

BRIDGEWATER, S., EGAN, C., 2002: International marketing relationship. 1st ed., New York: Palgrave, 288 p., ISBN 0-333-73377-0.

BRYSON, J. M., 2003: "What To Do When Stakeholders Matter: A Guide to Stakeholder Identification and Analysis Techniques", A paper presented at the London School of Economics and Political Science 10 February 2003, Acceptable from z http://cep.lse. ac.uk/seminarpapers/10-02-03-BRY.pdf [online] [cit.2003_08_19].

DAVIS, J., 2007: Measuring marketing: 103 Key Metrics Every Marketer Needs. John Wiley and Sons Pte Ltd, 408 p. ISBN 978-0-470-82132-9.

DeBONIS, J. N., BALINSKI, E., ALLEN, P., 2003: Value-Based Marketing for Botton-Line Success: 5 Steps to Creating Customer Value. New York: McGraw-Hill, 245 p., ISBN 0-07-139656-X.

GALBRAITH, J. R., 2005: Designing the Customer-Centric Organisation. A Guide to Strategy, Structure, and Process. San Francisco: Jossey-Bass, 184 p., ISBN 0-7879-7919-8.

GUENZI, P., TROILO, G., 2007: Developing Marketing Capabilities for Customer Value Creation Through Marketing - Sales Integration. Industrial Marketing Management, Vol. 35, Issue 8, pp. 974988, ISSN 0019-8501.

HARRISON, J. S., FREEMAN, R. E., 1999: „Stakeholders, Social Responsibility, and Performance: Empirical Evidence and Theoretical Perspectives", Academy of Management Journal 42 (5), 479-485, ISSN 1552-4205.

CHRISTOPHER, M., PAYNE, A., 2002: RM: Creating Stakeholder Value. Oxford,. 264 p. ISBN 0750648392.

KAPLAN, R. S. and BRUNS, W., 1987: Accounting and Management: A Field Study Perspective. Harvard Business School Press, ISBN 0-87584-186-4.

KOTLER, P., JAIN, D. C., MAESINCEE, S., 2007: Marketing Moves. New Approach to Profit, Growth and Reconditioning. $1^{\text {st }}$ Ed., Praha: Management Press, 171 s., ISBN 978-80-7261-161-4.

KOTLER, P., KELLER, K., L., 2007: Marketing Managament. 12. vyd. Praha: Grada Publishing, 788 s. ISBN 978-80-247-1359-5.
LOŠŤÁKOVÁ, H., 2005: B-to-B marketing: Strategická marketingová analýza pro vytvárení tržnich príležitostí. 1. vyd. Praha: Professional Publishing, 186 s. ISBN 80-86419-94-0. (B-to-B Marketing: Strategic Analysis to Creating of Marketing Opportunities).

LOŠŤÁKOVÁ, H., 2009: Diferencované ř́izení vztahů se zákazníky. 1. vyd. Praha: Professional Publishing, 268 s. ISBN 278-80-247-3155-1. (Customer Relationship Differentiation Management).

MITCHELL, R. K., AGLE, B. A, WOOD, D. J., 1997: „Toward a Theory of Stakeholders Identification and salince: Defining the Principles of Who and chat Really Counts", In Academy of Management Review. 22 (4), 853-886, [online] [cit. 20. 8. 2010] Accepted from http://aomonline.org/aom.asp?id=98.

PAYNE, A., 2005: Handbook of Customer Relationship Management: Achieving Excellence Through Customer Management. 288 p. ISBN 978-0-7506-6437-0.

PEPPERS, D., ROGERS, M., 2004: Managing Customer Relationships. A Strategic Framework. 1st ed., New Jersey: John Wiley\&Sons, 516 p., ISBN 0-471-48590$\mathrm{X}$.

PRAHALAD, C. K., RAMASWAMY, V., 2004: The Future of Competition: Co-Creating Unique Value with Customers. Boston: Harvard Business School Press, 257 p., 2004, ISBN 1-57851-953-5.

SMITH, B. J., COLGATE, M., 2007: Customer Value Creation: A Practical Framework. Journal of Marketing Theory and Practice. Vol. 15, No. 1, pp. 7-23, ISSN 1069-6679.

SHAW, R., 1999: Improving marketing effectiveness. 1st ed., London: Profile books Ltd, 244 p. ISBN 1861970544.

ŠIMBEROVÁ, I., 2008: Řízení relations se stakeholdy na průmyslových trzích $\mathrm{v}$ kontextu současných marketingových koncepcí. Habilitační a inaugurační spisy. Brno: Vutium, 38 s. ISBN 978-80-214-35858. (Stakeholders relationship Management on Industrial Markets in the Context of Present Marketing Concepts).

WINN, M. I., KELLER, L. R., 2001: „A Modeling Metodology for Multiobjective Multistakeholder Decisions: Implications for Research", In: Journal of Management Inquiry 10 (2), 166-181, [online] [cit. 20. 8. 2010] Accepted from http://www. uk.sagepub.com/journalsProdAbsIdx.nav?prodI $\mathrm{d}=$ Journal200922\&crossRegion=eur. 